Herz 2019 • 44:192-202

https://doi.org/10.1007/s00059-019-4789-4

Published online: 25 February 2019

(C) The Author(s) 2019

\author{
L. G. Mellbin ${ }^{1,2} \cdot$ A. Wang ${ }^{1} \cdot$ L. Rydén ${ }^{1}$ \\ ${ }^{1}$ Cardiology Unit, Department of Medicine K2, Karolinska Institutet, Stockholm, Sweden \\ ${ }^{2}$ Heart and Vascular Theme, Karolinska University Hospital, Stockholm, Sweden
}

\title{
Clinical implications of cardiovascular outcome trials in type 2 diabetes
}

tronic Health Records (CALIBER) program showed that during a median follow-up of 5.5 years, peripheral arterial disease and heart failure were the first presentation of cardiovascular events in, respectively, $16.2 \%$ and $14.1 \%$ of the individuals with T2DM [5]. In addition, patients with the combination of heart failure and T2DM have a poor prognosis [6]. It is important that the wide array of manifestations of CVD in people with $\mathrm{T} 2 \mathrm{DM}$ is taken into consideration when assessing cardiovascular risk and when setting up treatment plans. It is also of importance for the design and interpretation of cardiovascular outcome studies.

Hyperglycemia, the hallmark of T2DM, has been considered as the link between diabetes and CVD since this association was detected following the institution of insulin treatment in the 1920s [7, 8]. The connection between high blood glucose and CVD has been confirmed in several populations $[9,10]$. Not surprisingly, a majority of early pharmacological attempts to reduce such complications have focused on strict glycemic control.

\section{Cardiovascular outcome trials}

\section{Strict glycemic control}

Until recently, the majority of the trials on people with T2DM focused on glucose lowering either in the context of the effect of different drugs such as insulin and sulfonylureas or assessing different treatment strategies (e.g., intensive vs. less intensive).
The UK Prospective Diabetes Study (UKPDS) study, starting in 1977, comprised patients with newly detected T2DM. They were randomized to intensified glycemic control that was compared with conventional care. After 10 years, intensive glucose control by either sulfonylureas or insulin decreased the risk of microvascular but not of macrovascular complications [11]. In a posttrial follow-up a further 10 years later, and despite an early loss of glycemic differences between the study groups, a reduced risk for myocardial infarction $(15 \%, p=0.01)$ and death from any cause $(13 \%, p=0.007)$ emerged as more events occurred [12]. Furthermore, in the UKPDS 34 study [13], 342 overweight individuals were randomized to receive metformin or conventional care. A significant reduction in the occurrence of myocardial infarction was seen in the metformin arm at the initial follow-up already. This was sustained in the post-trial follow-up for myocardial infarction ( $33 \%, p=0.005)$, and death from any cause $(27 \%, p=0.002 ;[12])$. An important aspect to consider when interpreting these findings is that by contemporary means, the UKPDS patients received only to a very small extent effective lipid- $(0.3 \%)$ and blood-pressure lowering drugs (12\%) [11].

It is somewhat disappointing that the beneficial effect of intensive glucose lowering could not be verified in three trials published in 2009: the Action in Diabetes and Vascular Disease (ADVANCE; [14]), the Action to Control Cardiovascular Risk in Diabetes (ACCORD; [15]), and the Veterans Administration Diabetes 
Hier steht eine Anzeige.

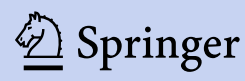


Main topic

Table 1 Side effects of various glucose-lowering drugs

\begin{tabular}{ll}
\hline Potential problem & Pharmacological agent \\
\hline Weight gain & Sulfonylureas, glinides, TZDs, insulin \\
\hline Gastrointestinal & Biguanides, a-glucosidase inhibitors \\
Hypoglycemia & Sulfonylureas, glinides, insulin \\
\hline Lactic acidosis & Biguanides \\
\hline$B_{12}$ deficiency & Biguanides \\
\hline Kidney dysfunction & Biguanides, sulfonylureas \\
\hline Urinary tract infection & SGLT-2 inhibitors \\
\hline Bladder cancer & TZDs \\
\hline Hepatic dysfunction & Glinides, TZDs, biguanides \\
\hline Pancreatitis & DPP-4 inhibitors, GLP-1 agonists \\
\hline Fractures & TZDs \\
Cardiovascular concerns & TZDs \\
\hline DPP dipeptidyl peptidase, GLP glucagon-like peptide, SGLT sodium-glucose cotransporter, \\
TZDs thiazolidinediones
\end{tabular}

Trial (VADT; [16]). These trials recruited patients suffering from diabetes for 8-11.5 years, of whom $32-40 \%$ had CVD. None of these studies, with a follow-up of 3.5-5.6 years, confirmed that intensive glucose lowering improved cardiovascular prognosis [17]. In fact, the ACCORD trial was prematurely stopped owing to an increased cardiovascular mortality rate among intensively managed subjects (HR: 1.35; CI 1.04-1.76; $p=0.02$; [15]). It was suggested that this was the result of an increased risk of severe hypoglycemia due to intensive glucose lowering. Indeed, post hoc analyses from these trials $[18,19]$ and other studies, e.g., the Outcomes Reduction with an Initial Glargine Intervention (ORIGIN) trial [20], show that severe hypoglycemia, regardless of treatment allocation, is associated with an impaired prognosis. Thus, it is important to avoid hypoglycemia since severe episodes may have a negative impact on survival and mild episodes can affect well-being and treatment inertia. Another potential explanation for the negative results may relate to the side effects of high dosages of glucose-lowering drugs used in different combinations [17, 21].

Reassuringly, a meta-analysis by Ray et al. [22], comprising UKPDS, ADVANCE, ACCORD, VADT, and the Pioglitazone vs. Placebo (PROACTIVE) studies [23], showed that an average reduction in HbA1c levels by $0.9 \%$ between patients randomized to intensive com- pared with conventional glycemic control was associated with a reduction of nonfatal myocardial infarction by $17 \%$ (OR: 0.83; 95\% CI: 0.75-0.93). It did, however, not affect total mortality (OR: 1.02; 95\% CI: 0.87-1.19).

Most international guidelines recommend an individualized glycemic target $[21,24]$. The present recommendations for glycemic control (HbAlc $\leq 7 \%$; $\leq 53 \mathrm{mmol} / \mathrm{mol}$ ) are mainly based on the prevention of microvascular complications, while evidence for the prevention of CVD is rather weak. For elderly or other fragile patients with long-standing or complicated T2DM, a less strict target ( $<7.5-8.0 \%$; $<58-64 \mathrm{mmol} / \mathrm{mol})$ is safer and thereby sufficient.

\section{Multifactorial management}

The cardiovascular risk is not related only to hyperglycemia. Type 2 diabetes mellitus is a multifactorial disease in which insulin resistance, endothelial dysfunction, and, e.g., factors such as hypertension and dyslipidemia play a contributory role. In fact, about $90 \%$ of patients with T2DM are overweight or obese and about $70 \%$ have hypertension and/or dyslipidemia [25-27]. In addition to the absolute excess risk for individuals with T2DM, the risk increases with increasing risk factor levels in people with T2DM compared with those without [28]. A multifactorial intervention was tested in the Steno-2 trial where patients with T2DM and mi- croalbuminuria were randomized to intensive, target-driven multifactorial therapy at a specialized clinic or to conventional care [29]. Strict targets were set for lifestyle as well as $\mathrm{HbAlc}$ and blood lipid levels, and blood pressure monitoring and treatment with a renin-angiotensin system inhibitor and aspirin were advocated in the intensively managed group. After 7.8 years, there was a $50 \%$ reduction in micro- and macrovascular events in this group. Thereafter, target-driven management was recommended for all participants. After 13 years of followup, the originally intensively managed patients had an absolute mortality reduction of $20 \%$, and a reduction of cardiovascular events of $29 \%$ [30], and after 21 years this reduction translated into 7.9 years of life gained [31], while the risk for hospitalization for heart failure was reduced by $70 \%$ [32].

The fundamental importance of multifactorial management of people with T2DM is emphasized in several guidelines, for example, the European Society of Cardiology guidelines on diabetes, prediabetes, and CVD from 2013 (update available August 2019; [21]).

\section{Concerns with glucose-lowering drugs}

In a meta-analysis by Nissen and Wolski published in 2007 [33], rosiglitazone-compared with several other glucose-lowering drugs, including metformin, sulfonylureas, and insulin-was associated with a $43 \%$ increased risk of myocardial infarction and a $64 \%$ increased risk for cardiovascular mortality. This analysis was later criticized because of the inclusion of several studies not representative for the study of cardiovascular outcomes and the negative results were never confirmed in subsequent analyses. Still, the study raised an intensive debate causing rosiglitazone to be withdrawn from the market. Furthermore, the cardiovascular safety of the drug class peroxisome proliferatoractivated receptor $\gamma$ (PPAR- $\gamma$ ) agonists, the thiazolidinediones, was questioned since these drugs were associated with fluid retention, increasing the risk of heart failure in sensitive patients. It was 
Herz 2019 · 44:192-202 https://doi.org/10.1007/s00059-019-4789-4

(c) The Author(s) 2019

\section{G. Mellbin · A. Wang $\cdot$ L. Rydén}

\section{Clinical implications of cardiovascular outcome trials in type 2 diabetes}

\section{Abstract}

Cardiovascular disease (CVD) is the main reason for premature death in patients with type 2 diabetes. Hyperglycemia, the hallmark of diabetes, has long been considered the link between diabetes and CVD, and many trials focused on preventing CVD manifestations by means of tight glucose control. However, diabetes is a multifactorial disease in which, e. g., insulin resistance, endothelial dysfunction, and factors such as hypertension and dyslipidemia contribute. Thus, treatment needs to be multifactorial and take cardiovascular aspects into account. Newer classes of drugs, originally launched for glucose lowering, among them dipeptidyl-peptidase (DPP)-4 inhibitors, sodium-glucose cotransporter (SGLT)-2 inhibitors, and glucagon-like peptide (GLP)1 receptor agonists, have been studied in large cardiovascular outcome trials (CVOT). Several SGLT-2 inhibitors and GLP-1 receptor agonists are associated with a reduction of cardiovascular events (cardiovascular death, nonfatal myocardial infarction, and nonfatal stroke). Although the mechanisms behind the effects are not fully understood, an important reason for the benefits of SGLT-2 inhibitors seems be a reduction in heart failure, while GLP-1 receptor agonists may retard the development of the atherosclerotic vascular disease or may be effective by stabilizing plaques. The outcomes of these studies have been taken into account in recently issued guidelines and an important task for diabetologists, cardiologists, and general practitioners is to incorporate the findings of these trials into clinical practice.

Keywords

Diabetes mellitus, adult-onset · Cardiac diseases - Sodium-glucose cotransporter 2 inhibitors · Dipeptidyl-peptidase 4 inhibitors . Glucagon-like peptide 1 receptor agonists

\section{Klinische Bedeutung kardiovaskulärer Endpunktstudien bei Typ-2-Diabetes}

\section{Zusammenfassung}

Kardiovaskuläre Erkrankungen (CVD) sind der Hauptgrund für einen vorzeitigen Tod bei Patienten mit Typ-2-Diabetes. Die Hyperglykämie, Kennzeichen des Diabetes mellitus, wurde lange als Bindeglied zwischen Diabetes und CVD angesehen, und viele Studien legten den Fokus auf die Prävention von CVD mittels strenger Glukoseeinstellung. Diabetes ist jedoch eine multifaktorielle Erkrankung, zu der z. B. Insulinresistenz, endotheliale Funktionsstörungen sowie Faktoren wie Hypertonie und Fettstoffwechselstörungen beitragen. Daher muss die Behandlung multifaktoriell sein und kardiovaskuläre Aspekte berücksichtigen. Neuere Substanzklassen bei Medikamenten, die ursprünglich zur Glukosesenkung eingeführt worden waren, darunter
Dipeptidylpeptidase(DPP)-4-Inhibitoren, Natrium-Glukose-Kotransporter(SGLT)-2Inhibitoren und Glucagon-like-Peptide(GLP)1-Rezeptoragonisten, sind in großen kardiovaskulären Endpunktstudien (CVOT) untersucht worden. Verschiedene SGLT-2Inhibitoren und GLP-1-Rezeptoragonisten gehen mit einer Verminderung kardiovaskulärer Ereignisse einher (kardiovaskulär bedingter Tod, nichtletaler Myokardinfarkt und nichtletaler Schlaganfall). Auch wenn die den Auswirkungen zugrunde liegenden Mechanismen nicht vollständig verstanden worden sind, scheint ein wichtiger Grund für den Nutzen von SGLT-2-Inhibitoren in einem selteneren Auftreten der Herzinsuffizienz zu bestehen, während GLP-1-Rezeptoragonisten möglicherweise die Entstehung atherosklerotischer Veränderungen der Gefäße verzögern oder durch Stabilisierung von Plaques wirken. Die Ergebnisse dieser Studien wurden in aktuell herausgegebenen Leitlinien berücksichtigt; eine wichtige Aufgabe für Diabetologen, Kardiologen und Allgemeinmediziner ist es, die Erkenntnisse aus diesen Studien in den klinischen Praxisalltag einzubringen.

\section{Schlüsselwörter}

Diabetes mellitus mit Beginn im Erwachsenenalter · Herzerkrankungen - NatriumGlukose-Kotransporter-2-Hemmer - Dipeptidylpeptidase-4-Hemmer - Glucagon-likePeptide-1-Rezeptoragonisten reassuring that the PROACTIVE trial showed that in patients with T2DM and high cardiovascular risk, pioglitazone reduced the secondary endpoint, a composite of death and nonfatal myocardial infarction or stroke (HR: 0.84 ; 95\% CI: $0.72-0.98 ; p=0.027$ ), while the reduction of the primary endpoint, including leg amputation and revascularization, did not reach statistical significance [23]. Nevertheless, these experiences raised the awareness of, sometimes serious, side effects related to the available glucoselowering drugs, as listed in • Table 1.
At the same time, at the beginning of this century, several new glucoselowering drug classes were developed and about to be released. Among them were dipeptidyl peptidase-4 (DPP-4) inhibitors, glucagon-like peptide-1 receptor agonists (GLP-1 RA), and sodium-glucose cotransporter-2 (SGLT-2) inhibitors. In 2008, the US Food and Drug Administration (FDA) issued guidance, subsequently also adopted by the European Medicines Agency (EMA), for the industry to ascertain the safety of these new glucose-lowering compounds: "Manufacturers developing new drugs in biologics for type 2 diabetes [are] to provide evidence that the therapy will not increase the risk of such cardiovascular events as a heart attack." The recommendations resulted in a large number of cardiovascular outcome trials (CVOTs) as outlined in - Table 2 and described in more detail in the next section.

\section{Cardiovascular outcome trials with new glucose-lowering agents}

\section{DPP-4 inhibitors}

The DPP-4 inhibitors are drugs that, by inhibiting its degrading DPP-4 en- 
Table 2 Cardiovascular outcome trials with glucose-lowering drugs (adapted from [40])

\begin{tabular}{|c|c|c|c|c|c|c|}
\hline Trial [ref.] & $\begin{array}{l}\text { Treatment } \\
\text { Active/ } \\
\text { comparator }\end{array}$ & Patient type $(n)$ & Primary endpoint & $\begin{array}{l}\text { Follow-up } \\
\text { median } \\
\text { (years) }\end{array}$ & $\begin{array}{l}\text { Outcome } \\
\text { HR }(95 \% \mathrm{CI}), p\end{array}$ & Remarks \\
\hline \multicolumn{7}{|l|}{$P P A R-\gamma$} \\
\hline $\begin{array}{l}\text { PROACTIVE } \\
{[23]}\end{array}$ & $\begin{array}{l}\text { Pioglitazone/ } \\
\text { placebo }\end{array}$ & $\begin{array}{l}\text { T2DM + macrovascular } \\
\text { disease (5238) }\end{array}$ & $\begin{array}{l}\text { A composite of all-cause } \\
\text { death, nonfatal MI, stroke, } \\
\text { ACS, endovascular or surgical } \\
\text { intervention in the coronary or } \\
\text { leg arteries, and amputation } \\
\text { above the ankle }\end{array}$ & 2.9 & $\begin{array}{l}\text { No difference } \\
0.90(0.80-1.02) \\
p=0.095\end{array}$ & $\begin{array}{l}\text { Secondary outcome } \\
\text { composite of CV } \\
\text { death and non- } \\
\text { fatal Ml or stroke } \\
0.84(0.72-0.98) ; \\
p=0.027\end{array}$ \\
\hline \multicolumn{7}{|l|}{ Insulin } \\
\hline ORIGIN [52] & $\begin{array}{l}\text { Insulin glargine/ } \\
\text { conventional }\end{array}$ & $\begin{array}{l}\text { T2DM, IFG, IGT + high } \\
\text { CV risk }(12,537)\end{array}$ & $\begin{array}{l}\text { Composite of CV death and } \\
\text { nonfatal MI or stroke }\end{array}$ & 6.2 & $\begin{array}{l}\text { No difference } \\
1.02(0.94-1.11) \\
p=0.63\end{array}$ & - \\
\hline $\begin{array}{l}\text { DEVOTE } \\
{[53]}\end{array}$ & $\begin{array}{l}\text { Insulin degludec/ } \\
\text { insulin glargine }\end{array}$ & $\begin{array}{l}\text { T2DM + CVD, renal } \\
\text { disease or high CV risk } \\
\text { (7637) }\end{array}$ & $\begin{array}{l}\text { Composite of CV death and } \\
\text { nonfatal MI or stroke }\end{array}$ & 1.9 & $\begin{array}{l}\text { No difference } \\
0.91(0.78-1.06) ; \\
p<0.001\end{array}$ & - \\
\hline \multicolumn{7}{|c|}{ SGLT-2 inhibitors } \\
\hline $\begin{array}{l}\text { EMPA-REG } \\
\text { Outcome } \\
\text { [39] }\end{array}$ & $\begin{array}{l}\text { Empagliflozin/ } \\
\text { placebo }\end{array}$ & T2DM + CVD (7020) & $\begin{array}{l}\text { Composite of CV death and } \\
\text { nonfatal MI or stroke }\end{array}$ & 3.1 & $\begin{array}{l}0.86(0.74-0.99) \\
p=0.0382\end{array}$ & $\begin{array}{l}\text { Decrease in heart } \\
\text { failure hospitaliza- } \\
\text { tion } \\
0.65(0.50-0.85) \\
p=0.002\end{array}$ \\
\hline $\begin{array}{l}\text { CANVAS } \\
\text { [41] }\end{array}$ & $\begin{array}{l}\text { Canagliflozin/ } \\
\text { placebo }\end{array}$ & $\begin{array}{l}\text { T2DM + high CV risk } \\
(10,142)\end{array}$ & $\begin{array}{l}\text { Composite of CV death and } \\
\text { nonfatal Ml or stroke }\end{array}$ & 2.4 & $\begin{array}{l}0.86(0.75-0.97) \\
p=0.02\end{array}$ & $\begin{array}{l}\text { Decrease in heart } \\
\text { failure hospitaliza- } \\
\text { tion } \\
0.67(0.52-0.87) \\
p<0.001\end{array}$ \\
\hline $\begin{array}{l}\text { DECLARE- } \\
\text { TIMI } 58 \text { [43] }\end{array}$ & $\begin{array}{l}\text { Dapagliflozin/ } \\
\text { placebo }\end{array}$ & $\begin{array}{l}\mathrm{T} 2 \mathrm{DM}+\mathrm{CVD} \text { or high CV } \\
\text { risk }(17,160)\end{array}$ & $\begin{array}{l}\text { Composite of CV death and } \\
\text { nonfatal MI or stroke }\end{array}$ & 4.2 & $\begin{array}{l}0.93(95 \% \mathrm{Cl} \\
0.84-1.03) p=0.17\end{array}$ & - \\
\hline \multicolumn{7}{|c|}{ DPP-4 inhibitors } \\
\hline TECOS [34] & $\begin{array}{l}\text { Sitagliptin/ } \\
\text { placebo }\end{array}$ & T2DM + CVD $(14,671)$ & $\begin{array}{l}\text { Composite of CV death and } \\
\text { nonfatal MI or stroke or hospi- } \\
\text { talization for UA }\end{array}$ & 3.0 & $\begin{array}{l}\text { No difference } \\
0.98(0.89-1.08) ; \\
p=0.65\end{array}$ & $\begin{array}{l}\text { No increase in heart } \\
\text { failure }\end{array}$ \\
\hline $\begin{array}{l}\text { EXAMINE } \\
{[35]}\end{array}$ & $\begin{array}{l}\text { Alogliptin/ } \\
\text { Placebo }\end{array}$ & $\begin{array}{l}\text { T2DM + recent ACS } \\
(5380)\end{array}$ & $\begin{array}{l}\text { Composite of CV death and } \\
\text { nonfatal MI or stroke }\end{array}$ & 1.5 & $\begin{array}{l}\text { No difference } \\
0.96(\leq 1.16) \\
p=0.32\end{array}$ & $\begin{array}{l}\text { No increase in heart } \\
\text { failure }\end{array}$ \\
\hline $\begin{array}{l}\text { SAVOR- } \\
\text { TIMI } 53 \text { [36] }\end{array}$ & $\begin{array}{l}\text { Saxagliptin/ } \\
\text { placebo }\end{array}$ & $\begin{array}{l}\mathrm{T} 2 \mathrm{DM}+\mathrm{CVD} \text { or high CV } \\
\text { risk }(16,492)\end{array}$ & $\begin{array}{l}\text { Composite of CV death and } \\
\text { nonfatal MI or stroke }\end{array}$ & 2.1 & $\begin{array}{l}\text { No difference } \\
1.00(0.89-1.12) \\
p=0.99\end{array}$ & $\begin{array}{l}\text { Increase in heart } \\
\text { failure hospital- } \\
\text { izations in the } \\
\text { saxagliptin group }\end{array}$ \\
\hline $\begin{array}{l}\text { CARMELINA } \\
\text { [37] }\end{array}$ & $\begin{array}{l}\text { Linagliptin/ } \\
\text { placebo }\end{array}$ & $\begin{array}{l}\mathrm{T} 2 \mathrm{DM}+\text { high } \mathrm{CV} \text { or } \\
\text { renal risk (6979) }\end{array}$ & $\begin{array}{l}\text { Composite of } \mathrm{CV} \text { death and } \\
\text { nonfatal MI or stroke }\end{array}$ & 2.2 & $\begin{array}{l}\text { No difference } \\
1.02 ; 95 \% \mathrm{Cl} \\
0.89-1.17 \\
p<0.001\end{array}$ & $\begin{array}{l}\text { No increase in heart } \\
\text { failure }\end{array}$ \\
\hline
\end{tabular}

zyme in a glucose-dependent manner, increase the incretin hormone levels (GLP-1, GIP), thereby increasing the pancreatic endogenous insulin secretion and suppressing glucagon. The DPP4 inhibitors sitagliptin [34], alogliptin [35], saxagliptin [36], and linagliptin [37] have been studied in large CVOTs (- Table 2) in populations of patients with T2DM at high cardiovascular risk. The impact on the primary endpoints (usually a standard major adverse coro- nary event $[\mathrm{MACE}]=$ a composite of cardiovascular death and myocardial infarction or stroke) were neutral in the Saxagliptin Assessment of Vascular Outcomes Recorded in Patients with Diabetes Mellitus (SAVOR) study [36], Examination of Cardiovascular Outcomes with Alogliptin Versus Standard of Care (EXAMINE) study [35], and Cardiovascular and Renal Microvascular Outcome Study With Linagliptin in Patients With Type 2 Diabetes Mellitus
(CARMELINA) trial [37]. In the Trial Evaluating Cardiovascular Outcomes with Sitagliptin (TECOS), hospitalization for unstable angina was also included [34]. The lack of improvement in cardiovascular prognosis may be explained by the fact that these trials were designed to shown noninferiority to placebo with short periods of follow-up, i.e., 1.5-3 years. Another explanation may be that DPP- 4 inhibitors are merely 
Hier steht eine Anzeige.

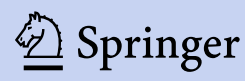




\begin{tabular}{|c|c|c|c|c|c|c|}
\hline Trial [ref.] & $\begin{array}{l}\text { Treatment } \\
\text { Active/ } \\
\text { comparator }\end{array}$ & Patient type (n) & Primary endpoint & $\begin{array}{l}\text { Follow-up } \\
\text { median } \\
\text { (years) }\end{array}$ & $\begin{array}{l}\text { Outcome } \\
\text { HR }(95 \% \mathrm{CI}), p\end{array}$ & Remarks \\
\hline \multicolumn{7}{|c|}{ GLP-1 receptor agonists } \\
\hline $\begin{array}{l}\text { LEADER } \\
{[45]}\end{array}$ & $\begin{array}{l}\text { Liraglutide/ } \\
\text { placebo }\end{array}$ & $\begin{array}{l}\text { T2DM + CVD or high CV } \\
\text { risk (9340) }\end{array}$ & $\begin{array}{l}\text { Composite of CV death and } \\
\text { nonfatal Ml or stroke }\end{array}$ & 3.8 & $\begin{array}{l}0.87(0.78-0.97) \\
p=0.01\end{array}$ & - \\
\hline $\begin{array}{l}\text { SUSTAIN-6 } \\
{[46]}\end{array}$ & $\begin{array}{l}\text { Semaglutide/ } \\
\text { placebo }\end{array}$ & $\begin{array}{l}\text { T2DM + CVD, renal } \\
\text { disease or high CV risk } \\
(2735)\end{array}$ & $\begin{array}{l}\text { Composite of CV death and } \\
\text { nonfatal Ml or stroke }\end{array}$ & 1.9 & $\begin{array}{l}0.74(0.58 \text { to } 0.95) \\
p<0.001\end{array}$ & $\begin{array}{l}\text { No increase in heart } \\
\text { failure }\end{array}$ \\
\hline $\begin{array}{l}\text { HARMONY- } \\
\text { OUTCOMES } \\
{[48]}\end{array}$ & $\begin{array}{l}\text { Albiglutide/ } \\
\text { placebo }\end{array}$ & T2DM + CVD (9463) & $\begin{array}{l}\text { Composite of CV death and } \\
\text { nonfatal Ml or stroke }\end{array}$ & 1.6 & $\begin{array}{l}0.78(0.68-0.90) \\
p<0.001\end{array}$ & - \\
\hline REWIND & $\begin{array}{l}\text { Dulaglutide/ } \\
\text { placebo }\end{array}$ & $\begin{array}{l}\text { T2DM + CVD or high CV } \\
\text { risk (9622) }\end{array}$ & $\begin{array}{l}\text { Composite of } \mathrm{CV} \text { death and } \\
\text { nonfatal Ml or stroke }\end{array}$ & $\begin{array}{l}\text { Not avail- } \\
\text { able }\end{array}$ & Not available & - \\
\hline $\begin{array}{l}\text { ELIXA } \\
{[50]}\end{array}$ & $\begin{array}{l}\text { Lixisenatide/ } \\
\text { placebo }\end{array}$ & T2DM + ACS (6068) & $\begin{array}{l}\text { Composite of CV death and } \\
\text { nonfatal MI or stroke or hospi- } \\
\text { talization for UA }\end{array}$ & 2.1 & $\begin{array}{l}\text { No difference } \\
1.02(0.89-1.17) \\
p=0.81\end{array}$ & $\begin{array}{l}\text { No increase in heart } \\
\text { failure }\end{array}$ \\
\hline $\begin{array}{l}\text { EXSCEL } \\
{[49]}\end{array}$ & $\begin{array}{l}\text { Exenatide/ } \\
\text { placebo }\end{array}$ & T2DM +/- CVD $(14,752)$ & $\begin{array}{l}\text { Composite of CV death and } \\
\text { nonfatal MI or stroke or hospi- } \\
\text { talization for UA }\end{array}$ & 3.2 & No difference & $\begin{array}{l}\text { No increase in heart } \\
\text { failure }\end{array}$ \\
\hline
\end{tabular}

glucose-lowering agents but without any direct cardiovascular effects.

An unexpected finding in the SAVOR study was that hospitalization for heart failure was significantly more common in patients randomized to saxagliptin than among those allocated to placebo $(3.5 \%$ vs. $2.8 \%$; HR: 1.27 ; $95 \%$ CI: $1.07-1.51$; $p=0.007)$. In the EXAMINE study, the corresponding HR was 1.19 (95\% CI: $0.90-1.58 ; p=0.220$ ). By contrast, no increased risk was seen for sitagliptin in the TECOS study (HR: 1.00; 95\% CI: $0.83-1.20 ; p=0.98 ;[34])$. The reasons for the increased risk of heart failure related to some incretins are not known but it is presumably not a class effect. The FDA issued a warning label in September 2017 for DPP-4 inhibitors regarding the risk of developing heart failure in patients with CVD and without any exception for sitagliptin, which, considering the available evidence, seems unfair.

\section{SGLT-2 inhibitors}

The SGLT-2 inhibitors increase urinary glucose excretion thereby improving glycemic control in an insulin-independent manner. Besides their glucoselowering effect, these drugs have the potential to impact the cardiovascular system indirectly, e.g., via weight loss, blood pressure lowering, or directly through osmotic diuresis and increased sodium excretion and presumably also by improving myocardial energetics (increased hematocrit and provision of beta-OH-butyrate [38]).

In the Empagliflozin Cardiovascular Outcome Event Trial in Type 2 Diabetes Mellitus Patients-Removing Excess Glucose (EMPA-REG), empagliflozin, compared with placebo, reduced the composite outcome of cardiovascular death or nonfatal myocardial infarction or stroke by $14 \%$ (HR: $0.86 ; 95 \%$ CI: $0.74-0.99 ; p=0.0382)$ in a patient population $(n=7020)$ with T2DM and established CVD during a median follow-up of 3.1 years (• Fig. 1; [39]). In particular, cardiovascular death was reduced, an effect that was seen already within a period of 15 weeks of followup, with a substantial reduction of heart failure (HR: 0.65; 95\% CI: 0.50-0.85; $p=0.0017)$ as the main driver. These results cannot be explained by the modest reduction in HbAlc levels $(-0.24 \%$, compared with placebo), advocating that SGLT-2 inhibitors have important beneficial cardiovascular effects besides glucose lowering [40].

Similar results have been presented for canagliflozin in the Canagliflozin Cardio- vascular Assessment Study (CANVAS) program in patients with a mean duration of diabetes of 135 years and 65\% with a history of CVD. The improvement in cardiovascular events amounted to $24 \%$ (HR: 0.86 ; 95\% CI: $0.75-0.97$; $p<0.001$ for noninferiority; $p=0.02$ for superiority; [41]). However, in addition to the known adverse events with SGLT2 inhibitors, most importantly genital infections, the CANVAS program reported on a small but significant increased risk of lower limb amputations. There was also a small increase in bone fractures but this finding was not confirmed in a large database investigation in which 79,964 patients initiated on canagliflozin were identified and matched to 79,964 patients initiated on a GLP-1 agonist (HR: 0.98; 95\% CI: 0.75-1.26; [42]).

In the recently published Dapagliflozin Effect on Cardio-vascular Events-Thrombolysis in Myocardial Infarction 58 (DECLARE-TIMI 58) trial [43], for 17,160 patients with T2DM who had or were at risk $(n=10,186)$ of atherosclerotic CVD, treatment with dapagliflozin did not result in a higher or lower rate of major cardiovascular events than placebo but in a lower rate of cardiovascular deaths or hospitalization for heart failure. 


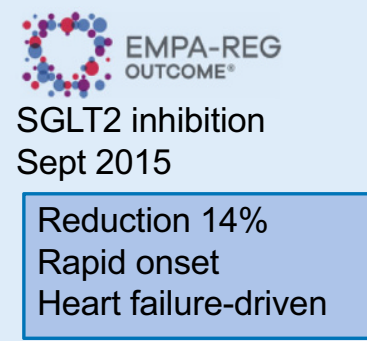

a

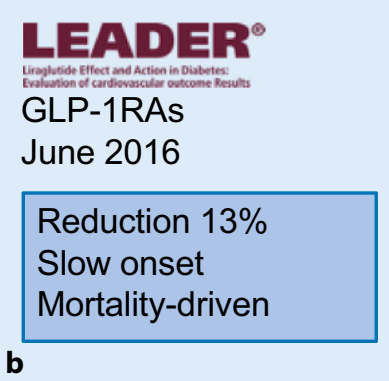

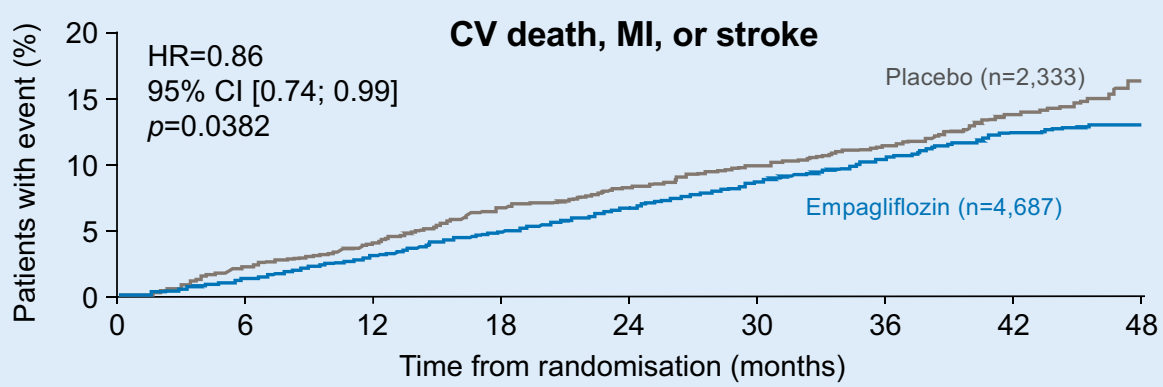

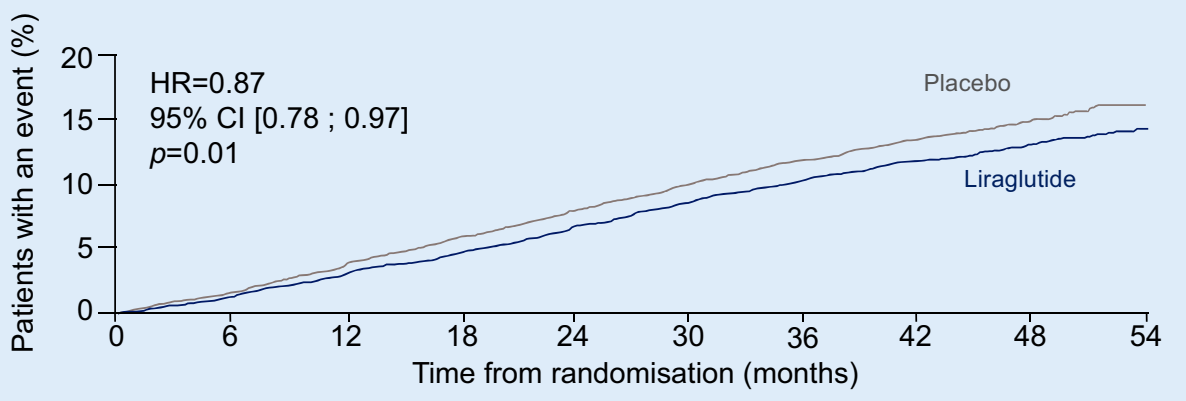

Fig. 1 A The impact of the sodium-glucose cotransporter 2 (SGLT2) inhibitor empagliflozin (a) and the glucagon-like peptide 1 (GLP-1) receptor agonist liraglutide (b) on the primary outcome in the EMPA-REG outcomes and LEADER trials, respectively. Both reduced the rates of cardiovascular death or non-fatal myocardial infarction or stroke to a similar extent (relative reduction $14 \%$ and $13 \%$, respectively). This outcome was, however, driven by different event reductions and appeared faster with empagliflozin than with liraglutide. $C l$ confidence interval, $C V$ cardiovascular, $H R$ hazard ratio, $M I$ myocardial infarction. (Modified after [39] and [45]. See text for further explanation)

In addition to the effects on the cardiovascular system, in particular related to heart failure, the three aforementioned SGLT-2 inhibitors were associated with improvements in the renal endpoints in the respective CVOT.

\section{GLP-1 receptor agonists}

The GLP-1 RAs improve glycemic control via the incretin hormone system. They are associated with improvements in several cardiovascular risk factors, among them body weight, blood pressure, and lipid levels. The GLP-1 receptors are widely distributed in the body. Through their impact on these factors it is reasonable to assume that GLP-1 RAs have pleiotropic effects such as a reduction of inflammatory activation and atherosclerosis progress, renal protection, and potentially even direct myocardioprotection [44].

In the Liraglutide Effect and Action in Diabetes: Evaluation of Cardiovascular Out-come Results (LEADER) trial, liraglutide was superior to placebo in reducing the primary composite MACE outcome (HR: 0.87; 95\% CI: 0.78-0.97; $p=0.01$; $\bullet$ Fig. 1 ). The absolute reduction (ARR) amounted to $1.9 \%$ over 3.8 years and included a decrease of all-cause mortality (HR: 0.85 ; 95\% CI: 0.74-0.97; $p=0.02$; ARR 1.4\%; [45]). Similar results were shown in the pre-marketing Trial to Evaluate Cardiovascular and Other Long-term Outcomes with Semaglutide in Subjects with Type 2 Diabetes (SUSTAIN-6), where semaglutide reduced MACE (HR: 0.74; 95\% CI: 0.58-0.95; $p=0.02$ for superiority). The ARR was $2.3 \%$ during 2.1 years in 3297 patients with T2DM and established or high risk for CVD [46]. The reduction in events was mainly driven by the rate of stroke rather than CVD death as in the LEADER study.

An unexpected finding was an increase in retinopathy, which in a sub hoc analysis was shown to mainly occur in those with pre-existing eye problems and presumably associated with the rapid reduction in glucose. A subsequent US population-based cohort study of older adults with diabetes suggests that incretin-based therapies, including GLP$1 \mathrm{RA}$, used for approximately 1 year, did not increase the retinopathy risk [47].

Recently, albiglutide was shown to be superior to placebo in the Harmony Outcomes in Reducing Cardiovascular Events (HARMONY Outcomes) trial $(p<0.0001$ for noninferiority; $p=0.0006$ for superiority; [48]) and a press release from the REWIND study indicates similar results for dulaglutide.

Interestingly, the beneficial effects on cardiovascular events of GLP-1 RA did not, in contrast to the SGLT-2 inhibitors, occur during the first phase of the trials. Taken together with animal and some small human studies, this suggests that it may be a result of improvements in inflammation and a retardation of the atherosclerotic process [44].

In contrast to the aforementioned trials, in the EXSCEL [49] and ELIXA studies [50], exenatide extended-release and lixisenatide were not inferior but also not superior to placebo in preventing cardiovascular events. Several potential explanations for the discrepant findings 
have been suggested. They may, for example, be related to differences in patient populations. All participants in the ELIXA trial had, in addition to T2DM, a recent acute coronary syndrome, and the proportion of patients at high risk for or already established CVD differed between the various trials. Other reasons may relate to the different drugs and molecules and to the different molecular size and biological half-life, particularly if the drugs are based on the synthetic exendin-4 (e.g., exenatide and lixisenatide) or on human GLP-1 analogues (liraglutide, semaglutide, dulaglutide, and albiglutide [44]).

\section{New versus old glucose-lowering drugs}

When it comes to older classes of glucoselowering drugs such as sulfonylureas, the impact on cardiovascular events has not been systematically investigated in randomized trials comparing them with DPP-4 inhibitors, GLP-1 RAs, or SGLT2 inhibitors. However, in a Swedish registry-based study, $77 \%$ of 52,760 patients who had been prescribed sulfonylurea as add-on glucose-lowering therapy to metformin were compared with the $23 \%$ of patients who instead had received a DPP-4 inhibitor. The crude incidence of all-cause mortality in the sulfonylurea cohort was 24.6/1000 patient-years compared with $14.9 / 1000$ patient-years in the DPP-4 cohort. Sulfonylurea compared with DPP-4 inhibition was associated with a higher risk of subsequent severe hypoglycemia, fatal and nonfatal cardiovascular disease, and all-cause mortality (adjusted HR: 2.07, 95\% CI: 1.11-3.86; HR: $1.17,95 \%$ CI: 1.01-1.37; and HR: 1.25, 95\% CI: $1.02-1.54$, respectively; [51]). A potential explanation may be the higher risk for prolonged hypoglycemia, in particular in vulnerable patients.

Data on exogenous insulin in this setting are also sparse. However, one of the first large CVOTs was ORIGIN, comparing insulin glargine with conventional glucose-lowering treatment in patients with T2DM, impaired glucose intolerance, and impaired fasting glucose at high cardiovascular risk. The hypoth- esis that early institution of basal insulin would improve the prognosis was, however, not confirmed as the effect was neutral between the randomized treatment groups [52]. In the DEVOTE trial, insulin degludec and glargine were comparable with respect to the incidence of major cardiovascular events [53].

\section{Interventions against insulin resistance}

The recent Insulin Resistance Intervention After Stroke (IRIS) study included 3876 patients free from type T2DM but insulin resistant according to the homeostasis model assessment of insulin resistance index (HOMA-IR) and with a recent ischemic stroke or transient ischemic attack. They were randomized to either pioglitazone or placebo. After 4.8 years of follow-up, $9.0 \%$ of the pioglitazonetreated patients compared with $11.8 \%$ in the placebo group had experienced the primary outcome, a composite of fatal or nonfatal stroke or myocardial infarction (HR: 0.76; 95\% CI: 0.62-0.93; $p=0.007$; [54]). Diabetes developed in $3.8 \%$ and $7.7 \%$ of the pioglitazone- and placebotreated patients, respectively. These trials suggest that improving insulin sensitivity, one of the main effects of the (PPAR$\gamma$ ) agonists, may not only reduce cardiovascular complications in patients with established diabetes but also in those in a pre-disease state.

\section{Gaps in knowledge}

The reasons why SGLT-2 inhibitors and GLP-1 receptors are associated with improvements in cardiovascular benefits are not fully understood. Further mechanistic studies are needed to clarify whether the beneficial effects relate to improvements in the cardiovascular risk factor profile or to pleiotropic cardiovascular effects, and the results of such studies need clinical verification. The CVOTs with SGLT-2 inhibitors suggest that the beneficial effects of these drugs are mediated by a decrease in heart failure. It should, however, be noted that these studies did not primarily study patients with heart failure or such events as primary outcomes. Trials with SGLT-2 inhibitors in patients with established heart failure, with or without diabetes, are ongoing and will hopefully shed further light. This is important, not least because heart failure is an important complication to T2DM as already underlined. GLP-1 RA may, as discussed, have an impact on the process of atherosclerosis.

Another important aspect is whether the beneficial effects of GLP-1 RA and SGLT-2 inhibitors are present in people without established CVD, early in the course of dysglycemia, e.g., the insulinresistant state and in pre-diabetes. Some studies, e. g., LEADER and REWIND, recruited patients with cardiovascular risk factors but free from established CVD, but it is still difficult to extrapolate the results to a primary preventive setting. To establish whether the drugs work in these states is of great interest mainly because there are indications from meta-analyses that people with a shorter duration of dysglycemia ( $<5$ years from onset of diabetes) benefit more from intensive glucose control, compared with treatment starting later or treatment in patients who have already developed signs of vascular damage [55].

Finally, the optimal glycemic target from a cardiovascular perspective remains to be defined. It could be that with the newer classes of drugs, with less risk of hypoglycemia in addition to their established cardiovascular effects, a more intensive glucose lowering may have added value.

\section{Conclusion}

An important task for the diabetology, cardiology, as well as the general practice communities is to incorporate the findings of the CVOTs into clinical practice. In a consensus report by the American Diabetes Association (ADA) and the European Association for the Study of Diabetes (EASD), it is stated that the presence of CVD and/or chronic kidney disease should be assessed. After the first-line therapies with metformin and comprehensive lifestyle interventions, SGLT- 2 inhibitors are recommended in people with heart failure and GLP-1 RAs in those with atherosclerotic CVD. 


\section{Corresponding address}

\section{Associate Professor L. G. Mellbin}

Heart and Vascular Theme, Karolinska

University Hospital

17176 Stockholm, Sweden

linda.mellbin@ki.se

\section{Compliance with ethical guidelines}

Conflict of interest L.G. Mellbin reports research grants from Bayer AG and lecture and/or consulting fees from Amgen, AstraZeneca, Boehringer-Ingelheim, Novo Nordisk, MSD, and Sanofi Aventis. L. Rydén reports research grants from the Swedish Heart-Lung Foundation, Family E. Persson's Foundation, Private Foundations, Stockholm County Council, Amgen, Bayer, Boehringer Ingelheim, MSD, Novo Nordisk, and lecture and/or consulting fees from AstraZeneca, Bayer, Boehringer-Ingelheim, Eli Lilly, MSD, Novo Nordisk, Sanofi. A. Wang declares that he/she has no competing interests.

This article does not contain any studies with human participants or animals performed by any of the authors.

Open Access This article is distributed under the terms of the Creative Commons Attribution 4.0 International License (http://creativecommons.org/licenses/by/ 4.0/), which permits unrestricted use, distribution, and reproduction in any medium, provided you give appropriate credit to the original author(s) and the source, provide a link to the Creative Commons license, and indicate if changes were made.

\section{References}

1. International Diabetes Federation (2017) IDF Diabetes Atlas Eighth Edition (http://www. diabetesatlas.org/.)

2. Biorck G, Sievers J, Blomqvist G (1958) Studies on myocardial infarction in Malmo 1935-1954. III. Follow-up studies from a hospital material. Acta Med Scand 162(2):81-97

3. Ritsinger V, Saleh N, Lagerqvist B, Norhammar A (2015) High event rate after a first percutaneous coronary intervention in patients with diabetes mellitus: results from the Swedish coronary angiography and angioplasty registry. Circ Cardiovasc Interv 8(6):e2328

4. ÅrsrapporterS.http://www.ucruuse/swedeheart/. Accessed 24 January 2019

5. Shah AD, Langenberg C, RapsomanikiE et al (2015) Type 2 diabetes and incidence of cardiovascular diseases: a cohort study in 1.9 million people. Lancet Diabetes Endocrinol 3(2):105-113

6. Johansson I, Dahlstrom U, Edner M et al (2015) Risk factors, treatment and prognosis in men and women with heart failure with and without diabetes. Heart 101(14):1139-1148

7. Levine $S$ (1929) Coronary thrombosis: its various clinical features. Medicine 8:245

8. Cryer PE (2009) Preventing hypoglycaemia: what is the appropriate glucose alert value? Diabetologia 52(1):35-37
9. Kuusisto J, Mykkanen L, Pyorala K, Laakso M (1994) NIDDM and its metabolic control predict coronary heart disease in elderly subjects. Diabetes 43(8):960-967

10. Stratton IM, Adler Al, Neil HA et al (2000) Association of glycaemia with macrovascular and microvascular complications of type 2 diabetes (UKPDS 35): prospective observational study. BM 321(7258):405-412

11. UKPDS33 (1998) Intensive blood-glucose control with sulphonylureas or insulin compared with conventional treatment and risk of complications in patients with type 2 diabetes (UKPDS 33). UK Prospective Diabetes Study (UKPDS) Group. Lancet 352(9131):837-853

12. Holman RR, Paul SK, Bethel MA et al (2008) 10-year follow-up of intensive glucose control in type 2 diabetes. NEngl J Med 359(15):1577-1589

13. UKPDS34 (1998) Effect of intensive blood-glucose control with metformin on complications in overweight patients with type 2 diabetes (UKPDS 34). UKProspective Diabetes Study (UKPDS) Group Lancet 352(9131):854-865

14. Patel A, MacMahon S, Chalmers J et al (2008) Intensive blood glucose control and vascular outcomes in patients with type 2 diabetes. N Engl J Med 358(24):2560-2572

15. Gerstein HC, Miller ME, Byington RP et al (2008) Effects of intensive glucose lowering in type 2 diabetes. NEngl J Med 358(24):2545-2559

16. Duckworth W, Abraira C, Moritz T et al (2009) Glucose control and vascular complications in veterans with type 2 diabetes. $\mathrm{N}$ Engl J Med 360(2):129-139

17. Skyler JS, Bergenstal R, Bonow RO et al (2009) Intensive glycemic control and the prevention of cardiovascular events: implications of the ACCORD, ADVANCE, and VA diabetes trials: a position statement of the American Diabetes Association and a scientific statement of the American College of Cardiology Foundation and the American Heart Association. Circulation 119(2):351-357

18. Seaquist ER, Miller ME, Bonds DE et al (2012) The impact of frequent and unrecognized hypoglycemia on mortality in the ACCORD study. Diabetes Care 35(2):409-414

19. Bonds DE, Miller ME, Bergenstal RM et al (2010) The association between symptomatic, severe hypoglycaemia and mortality in type 2 diabetes: retrospective epidemiological analysis of the ACCORD study. BMJ 340:b4909

20. Mellbin LG, Ryden L, Riddle MC et al (2013) Does hypoglycaemia increase the risk of cardiovascula events? A report from the ORIGIN trial. Eur Heart 34(40):3137-3144

21. Ryden L, Grant PJ, Anker SD et al (2013) ESC Guidelines on diabetes, pre-diabetes, and cardiovascular diseases developed in collaboration with the EASD: the Task Force on diabetes, prediabetes, and cardiovascular diseases of the European Society of Cardiology (ESC) and developed in collaboration with the European Association for the Study of Diabetes (EASD). Eur Heart J 34(39):3035-3087

22. Ray KK, Seshasai SR, Wijesuriya S et al (2009) Effect of intensive control of glucose on cardiovascular outcomes and death in patients with diabetes mellitus: a meta-analysis of randomised controlled trials. Lancet 373(9677):1765-1772

23. Dormandy JA, CharbonnelB,EcklandDJ etal (2005) Secondary prevention of macrovascular events in patients with type 2 diabetes in the PROactive Study (PROspective pioglitAzone Clinical Trial In
macroVascular Events): a randomised controlled trial. Lancet 366(9493):1279-1289

24. Davies MJ, D’Alessio DA, Fradkin J et al (2018) Management of hyperglycaemia in type 2 diabetes, 2018. A consensus report by the American Diabetes Association (ADA) and the European Association for the Study of Diabetes (EASD). Diabetologia 61(12):2461-2498

25. Bays HE, Chapman RH, Grandy S et al (2007) The relationship of body mass index to diabetes mellitus, hypertension and dyslipidaemia: comparison of data from two national surveys. Int J Clin Pract 61(5):737-747

26. Libby P, Ridker PM, Maseri A (2002) Inflammation and atherosclerosis. Circulation 105(9):1135-1143

27. Jacobs MJ, Kleisli T, Pio JR et al (2005) Prevalence and control of dyslipidemia among persons with diabetes in the United States. Diabetes Res Clin Pract 70(3):263-269

28. Stamler J, Vaccaro O, Neaton JD, Wentworth D (1993) Diabetes, other risk factors, and 12-yr cardiovascular mortality for men screened in the Multiple Risk Factor Intervention Trial. Diabetes Care 16(2):434-444

29. Gaede P, Vedel P, Larsen N et al (2003) Multifactorial intervention and cardiovascular disease in patients with type 2 diabetes. NEngl J Med 348(5):383-393

30. Gaede $\mathrm{P}$, Lund-Andersen $\mathrm{H}$, Parving $\mathrm{HH}$, Pedersen $O$ (2008) Effect of a multifactorial intervention on mortality in type 2 diabetes. $\mathrm{N}$ Engl J Med 358(6):580-591

31. Gaede P, Oellgaard J, Carstensen B et al (2016) Years of life gained by multifactorial intervention in patients with type 2 diabetes mellitus and microalbuminuria: 21 years follow-up on the Steno-2 randomised trial. Diabetologia 59(11):2298-2307

32. Oellgaard J, Gaede P, Rossing P et al (2018) Reduced risk of heart failure with intensified multifactorial intervention in individuals with type 2 diabetes and microalbuminuria: 21 years of follow-up in the randomised Steno-2 study. Diabetologia 61(8):1724-1733

33. Nissen SE, Wolski K (2007) Effect of rosiglitazone on the risk of myocardial infarction and death from cardiovascular causes. N Engl J Med 356(24):2457-2471

34. Green JB, Bethel MA, Armstrong PW et al (2015) Effect of sitagliptin on cardiovascular outcomes in type 2 diabetes. N Engl J Med 373(3):232-242

35. White WB, Cannon CP, Heller SR et al (2013) Alogliptin after acute coronary syndrome in patients with type 2 diabetes. $\mathrm{N}$ Engl J Med 369(14):1327-1335

36. Scirica BM, Bhatt DL, Braunwald E et al (2013) Saxagliptin and cardiovascular outcomes in patients with type 2 diabetes mellitus. NEngl J Med 369(14):1317-1326

37. Rosenstock J, Perkovic V, Johansen OE et al (2018) Effect of Linagliptin vs placebo on major cardiovascular events in adults with type 2 diabetes and high cardiovascular and renal risk: the CARMELINA randomized clinical trial. JAMA https://doi.org/10.1001/jama.2018.18269

38. Marx N, McGuire DK (2016) Sodium-glucose cotransporter-2 inhibition for the reduction of cardiovascular events in high-risk patients with diabetes mellitus. Eur Heart J37(42):3192-3200

39. Zinman B, Wanner C, Lachin JM et al (2015) Empagliflozin, cardiovascular outcomes, and mortality in type 2 diabetes. N Engl J Med 373(22):2117-2128

40. Ryden L, Shahim B, Mellbin L (2016) Clinical implications of cardiovascular outcome trials in 
type 2 diabetes: from DCCT to EMPA-REG. Clin Ther 38(6):1279-1287

41. Neal B, Perkovic V, Mahaffey KW et al (2017) Canagliflozin and cardiovascular and renal events in type 2 diabetes. N Engl J Med 377(7):644-657

42. Fralick M, Kim SC, Schneeweiss S et al (2019) Fracture risk after initiation of use of canagliflozin: a cohort study. Ann Intern Med. https://doi.org/10. 7326/M18-0567

43. Wiviott SD, Raz I, al Bonaca MPet (2018) Dapagliflozin and cardiovascular outcomes in type 2 diabetes. N Engl J Med. https://doi.org/10.1056/ nejmoa1812389

44. Drucker DJ (2016) The cardiovascular biology of Glucagon-like peptide-1. Cell Metab 24(1):15-30

45. Marso SP, Daniels GH, Brown-Frandsen K et al (2016) Liraglutide and cardiovascular outcomes in type 2 diabetes. NEngl J Med 375(4):311-322

46. Marso SP, Bain SC, Consoli A et al (2016) Semaglutide and cardiovascular outcomes in patients with type 2 diabetes. NEngl JMed. https:// doi.org/10.1056/nejmoa1607141

47. Wang T, Hong JL, Gower EW et al (2018) Incretinbased therapies and diabetic retinopathy: realworld evidence in older U.S. Adults. Diabetes Care 41(9):1998-2009

48. Hernandez AF, Green JB, Janmohamed $S$ et al (2018) Albiglutide and cardiovascular outcomes in patients with type 2 diabetes and cardiovascular disease (Harmony Outcomes): a double-blind, randomised placebo-controlled trial. Lancet 392(10157):1519-1529

49. Holman RR, Bethel MA, Mentz RJ et al (2017) Effects of once-weekly exenatide on cardiovascular outcomes in type 2 diabetes. $\mathrm{N}$ Engl J Med 377(13):1228-1239

50. Pfeffer MA, Claggett B, Diaz R et al (2015) Lixisenatide in patients with type 2 diabetes and acute coronary syndrome. N Engl J Med 373(23):2247-2257

51. Eriksson JW, Bodegard J, Nathanson D et al (2016) Sulphonylurea compared to DPP-4 inhibitors in combination with metformin carries increased risk of severe hypoglycemia, cardiovascular events, and all-cause mortality. Diabetes Res Clin Pract 117:39-47

52. Gerstein HC, Bosch J, Dagenais GRet al (2012) Basal insulin and cardiovascular and other outcomes in dysglycemia. N Engl J Med 367(4):319-328

53. Marso SP, McGuire DK, Zinman B et al (2017) Efficacy and safety of degludec versus glargine in type 2 diabetes. NEngl J Med 377(8):723-732

54. Kernan WN, Viscoli CM, Furie KL et al (2016) Pioglitazone after ischemic stroke or transient Ischemic attack. NEngl J Med 374(14):1321-1331

55. Turnbull FM, Abraira C, Anderson RJ et al (2009) Intensive glucose control and macrovascular outcomes in type 2 diabetes. Diabetologia 52(11):2288-2298

Traditionelle Chinesische Medizin

Fakultät für Sport-und Gesundheitswissenschaften

Technische Universität München

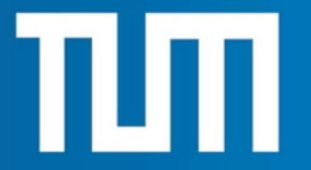

\section{Traditionelle Chinesische Medizin}

Europas erster Masterstudiengang

Der TCM Studiengang der TU München ist das erste akademisch-wissenschaftlich valide Angebot der westlichen Welt für das Erlernen dieser Form der Heilkunst. Der nur hier zu erwerbende Abschluss Master of Science (M.Sc.) unterstreicht dies. Der Studienleiter Prof. Hempen ist Internist und verfügt über vierzigjährige Lehrerfahrung unter Verwendung der chinesischen Originalquellen und ist Autor zahlreicher Standardwerke der TCM. In der Ausbildung dieses Masterstudiengangs werden Ärzte mit dem anderen Paradigma, der speziellen Diagnostik, der Physiologie und der Pathophysiologie sowie den therapeutischen Verfahren vertraut gemacht. Das wichtigste Therapieverfahren ist seit jeher die Chinesische Arzneitherapie. Erst an zweiter Stelle erscheint die bei uns bekanntere Therapie mit Akupunktur. Auch die weiteren Therapieformen wie Bewegungsübungen (Taiji, Qi Gong), die Diätetik und die Techniken der Manuellen Medizin (Tuina) werden unterrichtet.

\section{Einzigartig in der westlichen Welt}

- Chinesische Medizin auf wissenschaftlichem Niveau studieren

- Berufsbegleitend in sechs Semestern zum Master of Science (M.Sc.) Traditionelle Chinesische Medizin

- 120 CP in sechs Semestern

- Maximal 30 Studienplätze

- Zugangsvoraussetzung: Abgeschlossenes Medizinstudium

- Der praxisbezogene Blockunterricht findet in kleinen Gruppen statt. Genaue Termine finden Sie unter www.tcm.sg.tum.de

- Studiengebühr 4.200 Euro pro Semester

\section{Warum TCM?}

Der "Master of Science Traditionelle Chinesische Medizin" ermöglicht Ihnen:
- Eine erfüllende und ertragreiche privatärztliche Tätigkeitmit sehr wenig Konkurrenz.

- TCM nicht nur als punktuelle Ergänzung zur Schulmedizin zu betreiben, sondern als eigenständiges, hochwirksames System.

- Mit allen Sinnen Arzt zu sein, Zeit für die Patienten zu haben und dennoch gut zu verdienen.

- Teilhabe an einem der großen Entwicklungsschritte der modernen Medizin: TCM-Wissen und westliche Verfahren verbinden sich zu einer integrativen Heilkunst.

- Die Entwicklung dieser Synthese aktiv vorantreiben. Ganz vorne mitwirken an mehr Möglichkeiten in Diagnostik und Therapie - zum Wohle der Patienten.

Sie können sich für einen der 20 Studienplätze bewerben unter www.campus.tum.de. Das Bewerbungsfenster ist bis zum 15. Mai 2019 geöffnet. Bereits erworbenes TCM-Wissen und Abschlüsse können nach Prüfung anerkannt werden.

Für Mütter mit Kindern bzw. Familien Je nach Bedarf ist die TU bei der Organisation von Kinderbetreuung während der Anwesenheitszeiten der Studierenden unterstützend tätig.

Quelle:

Traditionelle Chinesische Medizin Fakultät für Sport- und Gesundheitswissenschaften Technischen Universität München Uptown München-Campus D Georg-Brauchle-Ring 60/62 80992 München, www.tcm.sg.tum.de Kontakt: Claudia Gerstberger Tel: 089/28924621, TCM@sg.tum 